\title{
Sex of children and family structure in Brazil: father \& grandmother bias?
}

\author{
Sarah Anne Reynolds*
}

Brazil has a high rate of mothers living without a partner as well as a high intergenerational co-residence rate, including parents and grandparents. These family types may influence a child's well-being. Even though there is no evidence of sex-selective abortion in Brazil, sex preference could still be subtly present. This paper tests the composition of family structure (father co-residence, grandmother co-residence, and birth of siblings) in Brazil associated with the sex of the child by using a nationally representative household survey, treating sex of the first and second child as exogenous variables in OLS regressions. I found women with lower birth-order daughters are less likely to live with a partner. I also found suggestive evidence that maternal grandmothers are more likely to live with granddaughters than with grandsons. Women with lower birth-order daughters are more likely to have additional children. Evidence suggests that in Brazil, fathers show a preference for sons over daughters, while grandmothers show a preference for granddaughters over grandsons. Additionally, mothers of girls, without co-residing partners may compensate for the economic loss caused by their lack of partner by living with their own mother. This contributes to the literature on child sex preferences, which has mostly focused on males (fathers); I have analyzed data on grandmothers to include females.

Keywords: Gender bias. Household composition. Grandmothers. Brazil.

\footnotetext{
* University of California, Berkelely, California, United States of America (sar48@berkeley.edu; https://orcid.org/00000002-2917-4579).
} 


\section{Introduction}

Household structure is crucial for child development because child development may be influenced, among other factors, by economic and time inputs from the adults in the child's environment. For example, Amato and Gilbreth's (1999) meta-analysis found that children raised in households without a father are economically disadvantaged. Similarly, additional siblings are often born to women who have more girls at lower-order births than boys, implying the girls will have fewer parental resources available to them. This paper examines whether household structure is associated to sex of children in Brazil. Brazil has high rates of women living without a partner, intergenerational co-residence, and a variation in number of children, so the context is ideal to see if these varied household structures are associated with child's sex. To the best of my knowledge, this is the first paper to include intergenerational household structures in the exploration of this topic.

\section{Household structure and child development}

Fathers can be an important factor influencing child development. In a meta-analysis, academic achievement and fewer behavioral problems were associated with fathers helping children with homework, listening to children's problems, providing emotional support, and setting boundaries (AMATO; GILBRETH, 1999). A review analysis confirmed lower levels of academic achievement and worse socio-emotional outcomes for children without fathers, though impacts were smaller than suggested by cross sectional studies (MCLANAHAN; TACH; SCHNEIDER, 2013). A review of studies from the US, Europe, and Israel showed that father engagement reduces behavioral problems in boys and psychological problems in girls, and, among low SES families, enhances cognitive development while decreasing delinquency and economic disadvantage (SAKARDI et al., 2008). These findings could be explained by the level of involvement of fathers who reside outside the household, which are often low, although fathers are in contact with their children, provide economic support, and participate in child-rearing decision making (SELTZER, 1991). An intervention to improve the relationship of divorced, non-coresident fathers with their children and exwives resulted in fewer internalizing problems for children (BRAVER; GRIFFIN; COOKSTON, 2005). Households with absent fathers have an associated lower overall income (THOMSON; HANSON; MCLANAHAN, 1994; AMATO, 2000) which, as a result, could imply child deprivation (SCHADY, 2006).

Grandparents can also influence child development. The presence of grandparents in the household reduces economic hardship for grandchildren in families led by singlemothers (MUTCHLER; BAKER, 2009). Academic performance of children with co-resident grandparents but non-coresident fathers are as good as those of children of married parents (DELEIRE; KALIL, 2002; AQUILINO, 1996). Dunifon and Kowaleski-Jones (2007) confirm this result in a longitudinal study, but only for White, not Black, families. A sociological literature review on Black extended families in the US, however, concludes that grandmothers in 
extended family households can benefit children through an indirect pathway by providing childcare and emotional support for mothers (WILSON, 1989).

Siblings may compete for parental attention and economic resources for schooling or health inputs must be divided among more children. Price (2008) shows firstborn children have better outcomes than children born later precisely because their parents give the firstborn their undivided time and attention, before the younger children are born. Additional children can also influence the mothers' labor supply and, thus, the economic resources available to the household (ANGRIST; EVANS, 1998).

\section{Literature on children's sex \& household structure}

US studies show fathers are more likely to be present in the household when their firstborn children are sons. As Lundberg summarizes literature on children's sex and household composition in the US, children's sex has small but significant impacts on the partnership status of parents and the living arrangement of the child: boys are more likely than girls to live with their father (LUNDBERG, 2005). Using US census data from 1960-2000, Dahl and Moretti (2008) find the sex of the firstborn child determines that each year in the US, 52,000 girls and their younger siblings do not co-reside with their fathers. This finding extends to women who have had ultrasounds revealing a son; these women are more likely to have a wedding prior to childbirth, than those conceiving a daughter. These findings are often explained by fathers' preference for sons - thus they are more willing to stay in a union with the mother - although other theories are plausible. Though son preference can result in benefits for the son, if the union maintained has substantial conflict, the resulting outcomes for the child are not always better than those of children in single-parent families (MUSICK; MEIER, 2010).

The preference for children of a particular sex can also manifest in fertility choices influencing household composition by changing the number of household members, which has implications for the division of resources. In India, son preference predicts girls will live in larger households which disadvantages girls with regard to educational attainment (JENSEN, 2003). Many international studies have found that the likelihood of having an additional child is higher when the first child is a girl. Hank and Kohler examined fertility stopping behavior in 17 European countries and found a lower likelihood of additional children when the first two were of mixed sex composition, but no significant difference regarding the children's sex composition. However, in three countries, including Portugal, there is an indication of higher increased fertility when the firstborn is a son (HANK; KOHLER, 2000). It will be interesting to see if Brazil shares this association with its colonizers. The associations between child's sex and subsequent fertility are often explained by parental preferences for children's sex composition. If the sex of the first child(ren) is not the ideal, the couple will often conceive another child. Since fertility is a shared decision, however, whether the preference for child's sex is mainly from the father or the mother is uncertain.

In the extreme examples, the sex of the child may determine whether the child enters the household. The sex ratio of boys to girls has been found to be higher than the natural 
rate in China and India, suggesting sex-selective abortion. In China, in 2005, the sex ratio of first order births was close to normal, but rose steeply for second order births (ZHUS; LU; HESKETH, 2009). Jah et. al. (2011) find that the sex ratio for second order births declined when the firstborn was a girl; this was strongest among wealthier women with more education, those who would likely have access to abortion services.

\section{The Brazilian context}

Brazil does not have a known culture of son (or daughter) preference, unlike the Asian countries described in the previous section. There is no evidence of sex-selective abortion in Brazil (CHIAVEGATTO FILHO; KAWACHI, 2013). However, economic inequality by sex is well known. For example, in 2008 , women in my analytical sample earned only $78 \%$ of what men did. The discrepancy in earnings is even more problematic when considering $89 \%$ of men were employed, whereas only $61 \%$ of women were (RENDALL, 2013). $18 \%$ of mothers ${ }^{1}$ in my analytical sample are not in union ${ }^{2}$ and their per capita monthly household income is 100 reais ( US\$50) less than that of mothers living in union. The economic imbalance influenced by the gender gap may be further exacerbated early in childhood if the sex of a child influences household composition and, thus, limits resources available to the child.

Three papers have indicated that Brazilian men favor sons while Brazilian women invest in their daughters. Thomas finds mother's education has a larger effect on daughter's stature, while father's education has a greater impact on son's stature. Women's nonlabor income has a positive effect on daughter's health, but not on son's health (THOMAS, 1994). Emerson and Souza (2007) discover comparable results with regard to labor market participation and schooling attendance. However, both of these papers limit their sample to two-parent families, and do not explore the possibility that sex bias could also be influencing household composition. These papers may fail to grasp the full impact of sex bias; the fathers' boy preference may influence the sample if fathers stay with the mother based on the sex of the child. Allyon and Ferreira-Batista (2015), however, do take into account the higher likelihood of men to stay in households with sons, and find children raised without a father in the home have worse nutrition outcomes. Additionally, in the 2006 PNDS survey, Brazilian women indicate a girl preference when responding to questions about ideal family composition. $71 \%$ were specific about the preferred sex of the children, with an overwhelming preference for one girl and one boy. Overall, a slight daughter preference was observed in women, with the total number of girls preferred by women in the ideal family being $3 \%$ higher than the total number of boys.

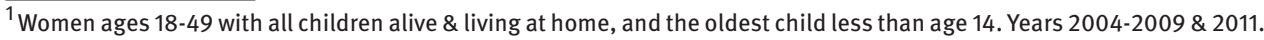
Additional descriptive statistics in the text refer to this population.

${ }^{2}$ I refer to women living with a male partner as in union, so this term also encompasses married women.
} 
Recent demographic changes in Brazil may make gender bias more salient now than in the past. In particular, there has been an increase in separations and a decrease in fertility (MAIA; SAKAMATO, 2016). With less social pressure to remain partnered due to the increase in separations, the preference for children's sex may play a larger role in the separation decision. With regard to fertility, in large families, a child of the desired sex is more likely, so the total number of children is less likely to be affected. In smaller families, however, the decision to have a second or third child may be affected by the gender composition of the previous children. This phenomena of stronger evidence of preference for child's sex has been seen in South Asia among wealthier families who tend to have fewer children (FILMER; FRIEDMAN; SCHADY, 2008).

These results suggest there may be associations between child's sex and father and mother presence (as well as additional siblings) in the Brazilian household. Yet most mothers live with their young children of both sexes, so there is little variation for exploring this question using mothers. Instead, I test if co-residence with grandmothers is associated with child's sex. Brazil is a particularly interesting location to explore this question. In Brazil, intergenerational families are not uncommon; 18\% of mothers in my analytical sample live with their own mother. Additionally, the urban population has a large portion of elder women living alone (MELO et al., 2016) consequently, a rise in the number of elderly persons in Brazil, has an effect on different sectors, especially family living arrangements. Objective: to analyze the socioeconomic profile of the family living arrangements of the elderly using PNAD micro-data (2009), suggesting that living with family can be a choice; preference for grandchild's sex could be a factor. A grandmother's presence should be beneficial for the child since the grandmothers present are on average 57 years old, young enough to still be actively participating in child care. Marteleto and Noonan (1988) find that ten percent of children in Brazil are primarily cared for by grandmothers, with this number higher among the youngest children. Grandmother care may be preferable due to emotional attachment, convenience, and the cost of alternate sources of care. Wheelock, Oughton, and Baines (2003) note the importance of grandparent childcare in England as a key feature allowing mothers to participate in the workforce, improving the household's economic position.

\section{Goal \& hypotheses}

Using a nationally representative survey, I test if child's sex is associated with household structure by testing if firstborn boys are more likely to have a father, a grandmother, or additional siblings in the household compared to firstborn girls. Because many women desire two or more children, I repeat these estimates examining the sex composition for the first two children, focusing particularly on the subset of women most likely to have more than one child. Based on the previous literature, my hypothesis is that female children are less likely to live with fathers, more likely to live with grandmothers, and more likely to have additional siblings. 


\section{Data}

Pesquisa Nacional por Amostra de Domicílios (PNAD) is Brazil's nationally representative household survey, a repeated cross section taken every year. I use data from 2004-2009 and 2011 for this analysis. 2004 is the year in which the survey becomes nationally representative and 2010 is omitted as it was the census year. While census microdata are publicly available for a sample of the population, due to the different sampling structure and a slightly different questionnaire, I refrain from including it in the analysis. I also exclude $1 \%$ of families from 2011 where the intra-household mother-child matching has data entry errors: the mother's id number is not found on the household roster. Using data from several years ensures the results of the analysis show general tendencies rather than focusing exclusively on a specific year which may have been an anomaly.

On the PNAD survey, women are asked about their fertility, including the number of boy and girl children alive, deceased, and living outside the household. On the roster, children's mothers are also identified in the survey. Matching children's characteristics to their mother, the ages of the mother's children living in the household were determined. Since it was impossible to ascertain the ages of those outside the household, the sample is limited to women aged 18-49 who have all their children alive and living with them. One concern is that children's sex may influence whether or not they live with their mother. I examine the percentage of children living with their mother by age and by sex; these begin to differ by sex around age 14, likely due to the higher rates of partnering among young women (Figure 1). Thus, I also limit the sample to women whose oldest child is age 13; before age 14 , girls are only $0.6 \%$ percentage points more likely to live with their mother than are boys, indicating a minimal selection bias. I also exclude women whose first birth was a multiple birth, determined by two or more children sharing the same birthday.

FIGURE 1

Living arrangements of children \& youth by sex Brazil - 2004/2011
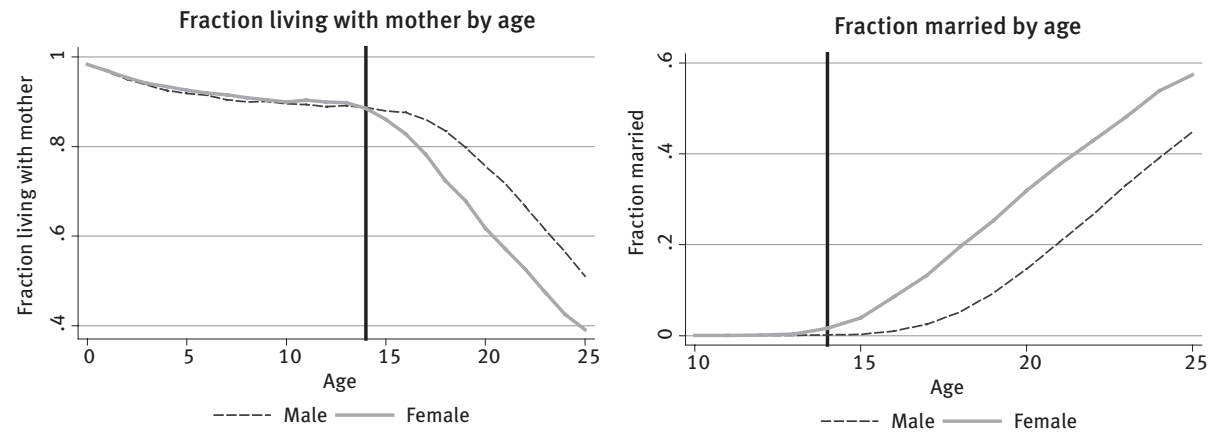

Source: PNAD 2004-2009, 2011.

Household structure outcome variables are determined from the household roster. All individuals are asked if their mother is alive and if she lives in the household. If she 
lives in the household, her ID is indicated, so her information can be linked to her child. However, fathers are not linked, thus I use the mother's union status as a proxy for if the child's father is in the household. From the household relationships reported in a question on the PNAD survey, whether or not an individual is in a union can be clearly determined in $92.5 \%$ of cases. ${ }^{3}$ On the household roster, spouses are directly identified, and in nuclear families where all other members are children of the head of household, I can assume that they are not in union with each other. In the other cases, I assume two individuals of the opposite sex are in union if they are not related to one another and are of similar ages. For example, a couple likely in union is a child of the head and another of the opposite sex who is of a similar age but not child of the head (usually indicated as "other relation"). In the regressions on union, I do not include this $7.5 \%$ of the population for whom the union status is imputed, but results are similar when they are included.

For the case where the maternal grandmother is alive, I know whether or not she lives with her grandchildren via the maternal linking of the individual IDs on the roster. The mother's answers to the questions about her mother determines if there is a maternal grandmother present for the children. Unfortunately, paternal grandmother presence is less clear. Children are not linked to their fathers on the survey; I can only infer fathers to be the partners of the children's mother. From the partner, I know whether or not his mother is alive and if she is living in the household. I use these responses as proxy indicators of paternal grandmother presence.

The presence of siblings is determined by other children in the household who have the same mother identified.

I also examine welfare outcomes by child's sex, such as educational enrollment and mothers' workload. However, since I do not know exactly how household structure contributes as a mechanism, this analysis is found in the appendix.

\section{Methods}

Identification lies on the randomness of child's sex, particularly that of the firstborn child. ${ }^{4}$ Attention is first given to the firstborn child for two reasons. Not all women have

\footnotetext{
${ }^{3}$ In 2009 \& 2011, a direct question regarding legal marital status was included on the survey. Comparing these questions with the categorization method explained above of those in union, I find a discrepancy between the estimated status and the actual status. In $38 \%$ of cases, the legal marriage status and living in union status did not align, highlighting a broad margin of informal partnering in Brazil. Not surprisingly, in 2011 a new question was added: "do you live with a partner?" This response aligns much better with the marriage status determined from household relationships; there is only a $0.6 \%$ discrepancy.

${ }^{4}$ Numerous studies have taken advantage of this variation as an identification strategy, but recently evidence suggests that child sex may not be random even without sex-selective abortion. The optimal evolutionary strategy for the species is to favor the offspring which will have more reproductive success. Males competing against other males will have more success when the environment is favorable; more females will be birthed when the population is under stress since the male's chance of reproducing is slimmer when he fails against competition (TRIVERS; WILLARD, 1973). Catalano et al. (2005) find an increase in male fetal deaths in California corresponding with economic downturns and Hamoudi and Nobles (2014) confirm that relationship conflict predicts more child sex with more girls born under stress. The fact that they also find that conflict predicts divorce suggest endogeneity within my analysis, which is a limitation.
} 
multiple children, so focusing on the first child allows for a broader sample size and conclusions of the widest applicability. Secondly, decisions to have subsequent children may be based on the sex of first child, resulting in a sample selection problem. Dahl and Moretti (2008) find a circumvention, pointing out that the sex of the first child will influence the sex composition of the first two children. For example, if the first child is a girl, it is impossible that the first two children are both boys. Thus, if sex bias is strong, the sex of the first child will be sufficient to identify it. This works well for them, as they find statistically significant results in almost every regression. Yet I do not always find statistical significance, which is an interesting contrast to the US. For a fuller analysis, I include results based on the sex composition of the first two children, as it may be the second child that tips the balance. For example, I find that women with firstborn sons are not statistically more likely to be in union. However, when looking at the sex of the first two children, when they are both male, the increased likelihood to be in union becomes statistically significant. This additional exploration imparts crucial information regarding sex bias that was inconclusive when only considering the first child.

On the other hand, without careful consideration, this information might be misleading. In developing countries where most women have at least two children, selection into the sample of women with two children may not be an issue. However, this is not the case in Brazil. The PNDS (National Survey of Demography and Health of Women and Children) responses indicate that for $15 \%$ of women, ideal household size only includes one child. Brazilian fertility is now below replacement, so many women are indeed choosing only to have one child, if any. In this nationally representative survey, by the time their first child reaches the age of five, $30 \%$ of Brazilian women do not have another child, and some never do. As presented in the results, I find that child's sex influences the likelihood of having another child and selection bias may be contaminating the results of the two-child analysis: if a woman is more likely to be in union if her firstborn is a boy, an increase in childbearing may be a result of more opportunities to reproduce, rather than a daughter preference. For this reason, and also because most women stated they preferred to have both a boy and a girl, it is important to look at the sex combinations of the first two children - not just the sex of first child - to test if the likelihood for additional children increases with girls being born.

There are selection correction methods, but few are appropriate. The methods that could be most easily implemented require the assumption of monotonicity: the selection process is only impacted in one direction by the variable of interest. In this case, however, it is ambiguous how the sex of the firstborn child will affect the outcome of having a second child. Under the assumption of son bias, if the child is male, the mother may have no more children, having achieved her goal of having a son. On the other hand, the father may be more willing to stay with the mother, so there are more opportunities for reproduction and more children may be born.

Without being able to correct for selection bias, the estimates examining the sex of the first two children will have to be interpreted as conditional estimates, not as population estimates. 
Since the subsample of women who have two or more children is large and interesting, this information will still be qualitatively useful. A more serious concern is that these estimates may not be accurate within this subsample if, as a result of selection, the characteristics of women with a firstborn boy are not comparable to women with a firstborn girl: comparing women with two boys to two girls makes little sense if these women are different. For example, perhaps a woman with firstborn girls and a second child has higher marital fitness than a woman with two children whose firstborn is a boy. The former was able to reproduce again after having a girl, whereas the appeal of a boy may keep a husband attached to a less fit wife. To test if these women are different - at least along observables - I would usually compare means of the observables by sex of the children. From the firstborns, however, I saw that child's sex already differs along observables. Instead, I examine if these differences have changed in determining the sex of the second child. If not, the observable characteristics (and hopefully also unobservable characteristics) of women producing firstborn boys are similar to those producing second born boys. I test this using the sample of all first and second born children by regressing the likelihood of being born male on the covariates. Then I add additional terms - $\mathrm{a}$ dummy for being a second born and interaction terms of this dummy with every covariate - and test their joint significance. The $p$-value for the test of joint significance is 0.554 , indicating the probability of being born male is no different for second born children than for firstborn children along the observables. I also confirm that the birth spacing of the second child is not statistically significant after a firstborn boy compared to a firstborn girl. These results should address some concerns about the comparability of the mothers.

For those whose still harbor concerns, and as a matter of general interest, I provide analysis of two subsamples where selection is not a concern. First, among women who have not completed high school and who gave birth at age 18 or less, only $15 \%$ - half of the rate among the general population - do not have a second child when their first child is of 5 years of age. For this population, the likelihood of having a second child is not statistically dependent on the first child's sex, as the fertility results will show later. Thus, estimates of the impact of the sex composition of the first two children will not pose a selection problem in this subpopulation. This subpopulation is of interest in its own right, as it is the most economically disadvantaged. Any sex bias in this population could worsen conditions for girls already at risk. I refer to this population as the vulnerable sample.

Additionally, I include estimates using women who had twins at first birth. In the PNAD data, children with the same birthday can be identified as twins. Selection into having a second child is no longer a concern, although a power issue remains, since there are only around 1300 mothers of firstborn twins in the survey. Although twins are unplanned and infertility treatments not widely used in Brazil, the incidence of twins is not entirely random. In this population, twins at the first parity are more likely to be found among younger mothers; this should be taken into account when interpreting the results.

In the regressions considering the sex of the first two children, instead of a first son dummy variable, I use two dummy variables: two boys and two girls. The base case is 
that of a boy and a girl. Statistically significant results indicate a difference from the base case. I also report the $p$-value of a test indicating whether the difference between the coefficients on these two dummies is significant, which would provide evidence supporting the hypothesis of sex preference.

To summarize, for each outcome variable, I will look at five sets of regressions. I will be testing the impact of having a firstborn son on the population as a whole, and also on the vulnerable population of women who have not finished high school and who gave birth to their first child in their teens. Afterwards, I will test the impact of the sex composition of the first two children on these two populations and additionally on the twin sample.

I use three specifications. The first one is a simple OLS regression. The second one includes population weights, and the final and preferred specification has both weights and controls (described later). Logit and probit models yield similar results but are not presented. In the results tables, below the coefficient of interest and standard error I present the baseline likelihoods of the outcome variable of a woman with a firstborn son and a woman with a firstborn daughter. These baselines are the predicted probability of the outcome variable of interest for firstborn boy families using the estimated coefficients on the control variables. These are used to calculate the percent change in likelihood of the outcome variable due to child's sex.

For these analyses, I pool data from all the years used from the PNAD. There are several reasons for this choice. First, it provides estimates spanning almost a decade, since an analysis of an individual year may represent an anomaly. Thus, the larger sample provides a broader picture of long-range tendencies. Secondly, analyses on individual year samples yield somewhat similar results (particularly for the outcome of women in union), but lack consistent statistical significance. Therefore, pooling the data provides more statistical power.

\section{Additional methods in addressing selection bias for grandmother presence}

When comparing maternal to paternal grandmother presence, the sample is limited to women in union whose mother and mother-in-law are alive, and estimates are found for both. However, when considering paternal grandmothers, the selection bias concern reappears, as I can only consider women who are in union, a variable potentially influenced by sex of the child. ${ }^{5}$ Fortunately, this selection process does satisfy the monotonicity assumption: in theory, a male child will make it more likely for a woman to be in union. Thus, a selection correction method is applicable. Unfortunately, though, a satisfactory exclusion restriction is not possible, so Heckman estimates would be unconvincing. Instead, I include calculations of Lee's bounds, nonparametric limits of the treatment effect only on those who are not influenced into selection by treatment ( LEE, 2009; TAUCHMANN, 2013). There are no exclusion restriction requirements. Lee's method involves trimming the sample so that the fraction of treated that select in is equal to the fraction of control individuals

\footnotetext{
${ }^{5}$ I assume the woman's mother or mother-in-law is alive and not influenced by the sex of her child. Indeed, the fraction of women with mother and mother-in-law alive is balanced by child sex in the data.
} 
that select in; the impact of selection bias is eliminated by ignoring the observations of those who have been induced into the sample because of the treatment. Unfortunately, I do not know who these individuals are. However, I can find bounds for the estimate by assuming two extreme cases: either they are the individuals with the highest value of the outcome variable or they are the individuals with the lowest values of the outcome variable. In this case, the outcome variables are the binomial "lives with mother" and "lives with mother-in-law." For example, assuming an equal number of boys and girls born. If selection implied that $75 \%$ of women with boys remained in union, compared to only $70 \%$ of women with girls, the group with sons would be trimmed down to $70 \%$. The excess $5 \%$ is removed - after excluding women who live with their mothers and excluding women who do not - to bind the estimate. The resulting comparisons yield two bounds on the effect of the sex of the child influencing grandmother presence on individuals who would have continued to be in union regardless the sex of the child. For the lower bound, the treated with the highest outcome values are eliminated, and for the upper bound, the treated with the lowest outcome values are eliminated.

\section{Control variables}

I use different control variables. Examining the likelihood of having a firstborn male among this Brazilian population in Table 1, I find statistically significant correlations with two covariates, education and region, suggesting differences in stress faced by different populations could indeed be affecting sex ratios. ${ }^{6}$ If these covariates fully capture unobserved differences in the child's sex selection process, the problem can be interpreted as a "selection on observables" problem. Thus when examining the impact of child's sex on household composition by testing if the sex of a woman's firstborn child influences a variety of binomial outcomes, it is important to include these controls (education and the region dummy variables). Additional controls are the woman's age, age cubed, age of first child, a dummy indicating if her mother is alive, a rural dummy, and dummy variables indicating the survey year.

\footnotetext{
$\overline{6}$ The main concern for identification is that there are still additional factors affecting sex selection. If living in union with a partner reduces stress, males will be more likely to be born and the causal interpretation is lost. In a US sample, (NORBERG, 2004) finds respondents who were living with a spouse or partner before the child's conception or birth to have had $51.5 \%$ males, and 49.9\% males were born to respondents who were not partnered (2004). Likewise, (HAMOUDI; NOBLES, 2014) marriages producing firstborn daughters are more likely to divorce than those producing firstborn sons. The findings have been interpreted as contemporary evidence of fathers' son preference. Our study explores the potential role of another set of dynamics that may drive these patterns: namely, selection into live birth. Epidemiological evidence indicates that the characteristic female survival advantage may begin before birth. If stress accompanying unstable marriages has biological effects on fecundity, a female survival advantage could generate an association between stability and the sex composition of offspring. Combining regression and simulation techniques to analyze real-world data, we ask, How much of the observed association between sex of the firstborn child and risk of divorce could plausibly be accounted for by the joint effects of female survival advantage and reduced fecundity associated with unstable marriage? Using data from the National Longitudinal Survey of Youth (NLSY79) find relational stress correlated with child sex and divorce. Unfortunately, due to the lack of marital history in PNAD data, there is no way to test or control for this selection in the study. I will continue with the working assumption, as does most of the literature, that sex of the first child is exogenous to household composition. Hopefully, future research on Brazil can incorporate this aspect into the models and also consider the stress of living with parents when pregnant in addition to spousal stress.
} 
TABLE 1

Descriptive statistics by child's sex

Brazil - 2004/2011

\begin{tabular}{lrrrrr}
\hline \multirow{2}{*}{ Variables } & \multicolumn{5}{c}{ Sex of first born child } \\
\cline { 2 - 6 } & \multicolumn{2}{c}{ Girl } & \multicolumn{3}{c}{ Boy } \\
\cline { 2 - 6 } Mean & SD & Mean & SD & Pr > t \\
\hline Woman's age & 104,317 & & 110,430 & 0.380 \\
Child's age & 29.42 & 6.40 & 29.40 & 6.40 & 0.270 \\
Years of education & 6.60 & 3.96 & 6.58 & 3.95 & 0.037 \\
Mother is alive & 8.61 & 3.79 & 8.64 & 3.77 & 0.789 \\
North & 0.88 & 0.32 & 0.88 & 0.32 & 0.058 \\
Northeast & 0.14 & 0.35 & 0.14 & 0.35 & 0.948 \\
South & 0.31 & 0.46 & 0.31 & 0.46 & 0.960 \\
Southeast & 0.28 & 0.45 & 0.28 & 0.45 & 0.702 \\
Central-west & 0.15 & 0.35 & 0.15 & 0.35 & 0.135 \\
Rural & 0.11 & 0.32 & 0.11 & 0.32 & 0.125 \\
\hline
\end{tabular}

Source: PNAD 2004-2009, 2011.

\section{Results}

\section{Mother's union status}

Figure 2 illustrates the fraction of mothers of firstborn sons who were in union compared to the fraction of mothers of firstborn daughters who were in union. In every year, except for 2005 , women with firstborn sons were more likely to be in union than those with firstborn daughters. Consistency over time suggests that a sex bias indeed exists.

FIGURE 2

Fraction of women in union by sex of first child Brazil - 2004-2011

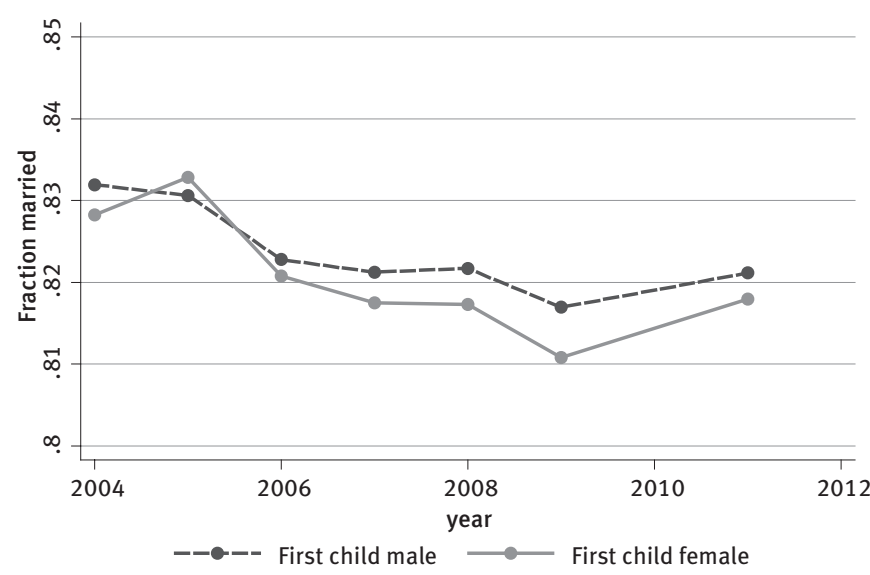

Source: PNAD 2004-2009, 2011. 
Around $80 \%$ of mothers are in union (Table 2). For the sample as a whole, the sex of the first child does not affect union status at a statistically significant level. However, for the subpopulation of most vulnerable women, women with boys are $1.2 \%$ more likely to be in union than women with girls (Table 2, "In Union" columns). In both the population as a whole and the vulnerable population, mothers of two girls are less likely to be in union than mothers with a boy and a girl as the first two children, which is the base category against which these variables are compared. (It must be borne in mind that the vulnerable population does not have the same selection issue with having additional children based on the sex of the first child.) However, only in the population as a whole are mothers of two girls statistically less likely to be in union than mothers of two boys, as indicated by the $p$-value of the t-test comparing the coefficients on two girls \& two boys. These results suggest that for the population as a whole there is a boy bias, which may be intensified among the vulnerable population. Although in the vulnerable population, the difference between the union status of mothers with two girls and two boys is not significant, the magnitude of the difference is larger than in the population as a whole. In either case, having at least one boy is a small protection against singleness among these mothers with two children. No statistically significant correlation between union status and sex of children is found for mothers of twins, although the sample size may be underpowered.

The study also includes an examination of the subset of children who do not have a mother alive to determine if the father is more likely to be present for boy or girl children, and if outcomes for those who have lost their mother differ by sex of the child. If the child is identified as the son/daughter of a male household head, they are coded as living with the father. One limitation to this analysis is that if the father is not the household head but still lives in the household, I would not be able to identify that relationship. Of a sample of almost 6,000 children age 13 or less, I find boys are significantly more likely to live with their fathers than girls: $52 \%$ of boys with a deceased mother live with fathers, while $49 \%$ of girls without mothers do ( $95 \%$ confidence). The magnitude and significance are consistent when controlling for child's age, age cubed, and including region and rural dummies. (Regressions not included in tables.) 
TABLE 2

OLS Regressions of mother being in union or living with her mother (the child's grandmother) based on child's sex

Brazil - 2004/2011

\begin{tabular}{|c|c|c|c|c|c|c|c|}
\hline & \multirow{3}{*}{$\begin{array}{l}\begin{array}{l}\text { Outcome } \\
\text { variable }\end{array} \\
\text { weights } \\
\text { controls }\end{array}$} & \multicolumn{3}{|c|}{ Living in union } & \multicolumn{3}{|c|}{$\begin{array}{l}\text { Lives with mother (women } \\
\text { whose mother is alive) }\end{array}$} \\
\hline & & $n$ & $y$ & $y$ & $\mathrm{n}$ & $y$ & $y$ \\
\hline & & $\mathrm{n}$ & $\mathrm{n}$ & $y$ & $\mathrm{n}$ & $\mathrm{n}$ & $y$ \\
\hline \multirow{6}{*}{$\begin{array}{l}\text { Entire sample - } \\
\text { first child }\end{array}$} & First son & $0.0042^{\star}$ & 0.0027 & 0.0027 & 0.0007 & 0.0011 & 0.0005 \\
\hline & & $(0.0017)$ & $(0.0019)$ & $(0.0019)$ & $(0.0016)$ & $(0.0017)$ & $(0.0017)$ \\
\hline & Girl baseline & 0.8150 & 0.8210 & 0.8214 & 0.1223 & 0.1197 & 0.1201 \\
\hline & Boy baseline & 0.8192 & 0.8238 & 0.8241 & 0.1230 & 0.1208 & 0.1206 \\
\hline & Percent effect (\%) & 0.5 & 0.3 & 0.3 & 0.6 & 0.9 & 0.4 \\
\hline & Observations & 198470 & 198470 & 196464 & 173644 & 173644 & 172303 \\
\hline \multirow{6}{*}{$\begin{array}{l}\text { Vulnerable sample } \\
\text { - first child }\end{array}$} & First son & $0.0111^{\star \star}$ & $0.0103^{*}$ & $0.0098^{*}$ & -0.0033 & -0.0025 & -0.0029 \\
\hline & & $(0.0039)$ & $(0.0043)$ & $(0.0042)$ & $(0.0036)$ & $(0.0039)$ & $(0.0038)$ \\
\hline & Girl baseline & 0.8114 & 0.8160 & 0.8163 & 0.1342 & 0.1305 & 0.1307 \\
\hline & Boy baseline & 0.8225 & 0.8263 & 0.8262 & 0.1309 & 0.1279 & 0.1277 \\
\hline & Percent effect (\%) & 1.4 & 1.3 & 1.2 & -2.5 & -2.0 & -2.3 \\
\hline & Observations & 38710 & 38710 & 38594 & 34837 & 34837 & 34837 \\
\hline \multirow{9}{*}{$\begin{array}{l}\text { Entire sample - } \\
\text { first two children }\end{array}$} & Two girls & $-0.0051+$ & $-0.0055+$ & $-0.0059+$ & 0.0009 & 0.0025 & 0.0029 \\
\hline & & $(0.0028)$ & $(0.0030)$ & $(0.0030)$ & $(0.0023)$ & $(0.0025)$ & $(0.0025)$ \\
\hline & Two boys & 0.0020 & 0.0015 & 0.0012 & -0.0004 & 0.0005 & -0.0001 \\
\hline & & $(0.0027)$ & $(0.0029)$ & $(0.0029)$ & $(0.0022)$ & $(0.0024)$ & $(0.0024)$ \\
\hline & p-value & 0.024 & 0.041 & 0.040 & 0.625 & 0.494 & 0.293 \\
\hline & Girl baseline & 0.8576 & 0.8621 & 0.8623 & 0.0786 & 0.0772 & 0.0778 \\
\hline & Boy baseline & 0.8647 & 0.8690 & 0.8693 & 0.0773 & 0.0752 & 0.0748 \\
\hline & Percent effect (\%) & 0.8 & 0.8 & 0.8 & -1.7 & -2.6 & -3.9 \\
\hline & Observations & 96719 & 96719 & 95594 & 83193 & 83193 & 82459 \\
\hline \multirow{9}{*}{$\begin{array}{l}\text { Vulnerable sample } \\
\text { - first two children }\end{array}$} & Two girls & $-0.0114^{\star}$ & $-0.0150^{\star}$ & $-0.0154^{\star}$ & 0.0052 & $0.0095+$ & $0.0098+$ \\
\hline & & $(0.0056)$ & $(0.0062)$ & $(0.0061)$ & $(0.0049)$ & $(0.0053)$ & $(0.0053)$ \\
\hline & Two boys & 0.0010 & -0.0050 & -0.0070 & -0.0031 & -0.0005 & -0.0000 \\
\hline & & $(0.0054)$ & $(0.0059)$ & $(0.0059)$ & $(0.0046)$ & $(0.0050)$ & $(0.0049)$ \\
\hline & p-value & 0.052 & 0.156 & 0.226 & 0.132 & 0.098 & 0.097 \\
\hline & Girl baseline & 0.8401 & 0.8410 & 0.8414 & 0.0979 & 0.0981 & 0.0982 \\
\hline & Boy baseline & 0.8525 & 0.8510 & 0.8499 & 0.0897 & 0.0882 & 0.0884 \\
\hline & Percent effect (\%) & 1.5 & 1.2 & 1.0 & -8.4 & -10.1 & -9.8 \\
\hline & Observations & 25474 & 25474 & 25391 & 22557 & 22557 & 22557 \\
\hline \multirow{9}{*}{$\begin{array}{l}\text { Twin Sample - first } \\
\text { two children }\end{array}$} & Two girls & -0.0168 & -0.0201 & 0.0035 & 0.0115 & 0.0111 & 0.0130 \\
\hline & & $(0.0271)$ & $(0.0296)$ & $(0.0298)$ & $(0.0269)$ & $(0.0306)$ & $(0.0314)$ \\
\hline & Two boys & -0.0220 & -0.0221 & -0.0105 & $-0.0442+$ & -0.0431 & -0.0409 \\
\hline & & $(0.0278)$ & $(0.0302)$ & $(0.0303)$ & $(0.0256)$ & $(0.0294)$ & $(0.0293)$ \\
\hline & p-value & 0.834 & 0.942 & 0.607 & 0.012 & 0.032 & 0.034 \\
\hline & Girl baseline & 0.8144 & 0.8142 & 0.8255 & 0.1538 & 0.1563 & 0.1571 \\
\hline & Boy baseline & 0.8092 & 0.8122 & 0.8115 & 0.0981 & 0.1021 & 0.1032 \\
\hline & Percent effect (\%) & -0.6 & -0.3 & -1.9 & -36.2 & -34.7 & -35.5 \\
\hline & Observations & 1319 & 1319 & 1305 & 1170 & 1170 & 1160 \\
\hline
\end{tabular}

Source: PNAD 2004-2009, 2011.

Note: Robust standard erros p-values significance: $+0.10 * 0.05 * * 0.01$

Controls are woman's age, age cubed, age of first child, years of education, a dummy for if her mother is alive, and dummies indicating region, survey year, and rural location.

P-value is the significance of the test of differences in coefficients two girls \& two boys. 


\section{Grandmother presence}

I test whether grandmother presence in the household is associated with grandchild's sex. In Table 3 ("Lives with Mother" columns), I find no statistically significant evidence that women with firstborn sons are more likely to live with their mothers, both looking at the population as a whole and at the more vulnerable population. A difference is observed when looking at the first two children, however, only between the vulnerable sample and the mother of twins. In both cases, women are more likely to live with their mother if they have two girls rather than two boys. For contrasting maternal and paternal grandmother cohabitation, the sample is limited to women in union whose mothers are alive and whose husband's mothers are alive. A paternal grandmother (mother-in-law) is more likely to be present when the woman's firstborn is male, but only in the vulnerable population (Table 3).

Figure 3 includes bounds of estimates from Table 3 and Table 4 and their confidence intervals. For estimates regarding the sex of the first two children, the comparison is between two girls and two boys; families with a boy and a girl are excluded. The positive side of the axis means the grandmother is more likely to live with boys. The results show estimates indicate plausible granddaughter preference by grandmothers to the children of couples who would not be influenced by child's sex to divorce. While all confidence intervals include 0 , the bounds themselves are both negative for maternal grandmothers of twins: a mother of twin girls is more likely to have her mother living in the household than mothers of twin boys. Another interesting finding, with both bounds below zero, is that for the entire population there is an increased likelihood of paternal grandmothers to live with daughters-in-law with firstborn daughters than daughters-inlaw with firstborn sons.

FIGURE 3

Lee's bounds results graph. $X$ axis values indicate the likelihood of grandmother presence if the child is a boy compared to a girl; positive values are associated with a larger grandmother presence if the child is male

Brazil - 2004/2011
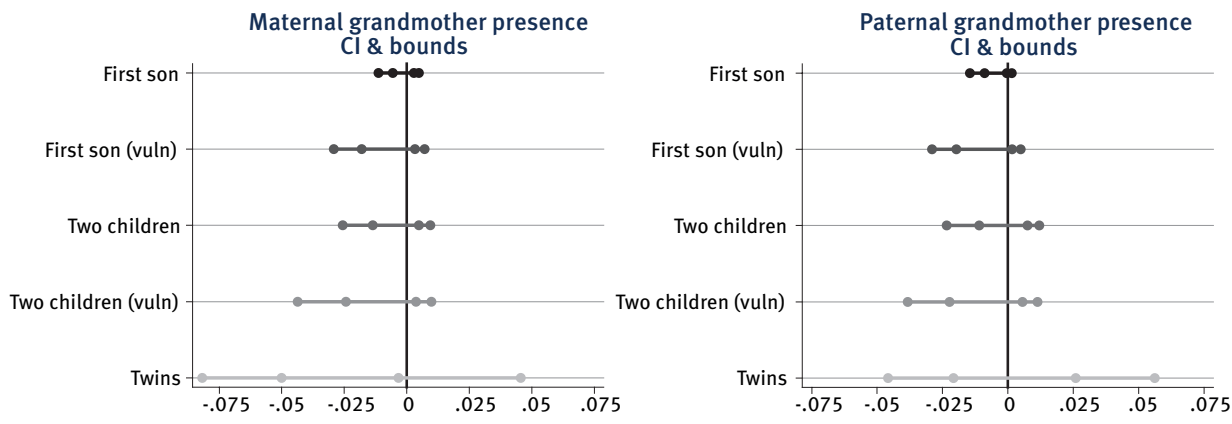

Source: PNAD 2004-2009, 2011. 
TABLE 3

OLS Regressions of likelihood of living with child's maternal or paternal grandmother based on child's sex

Brazil - 2004/2011

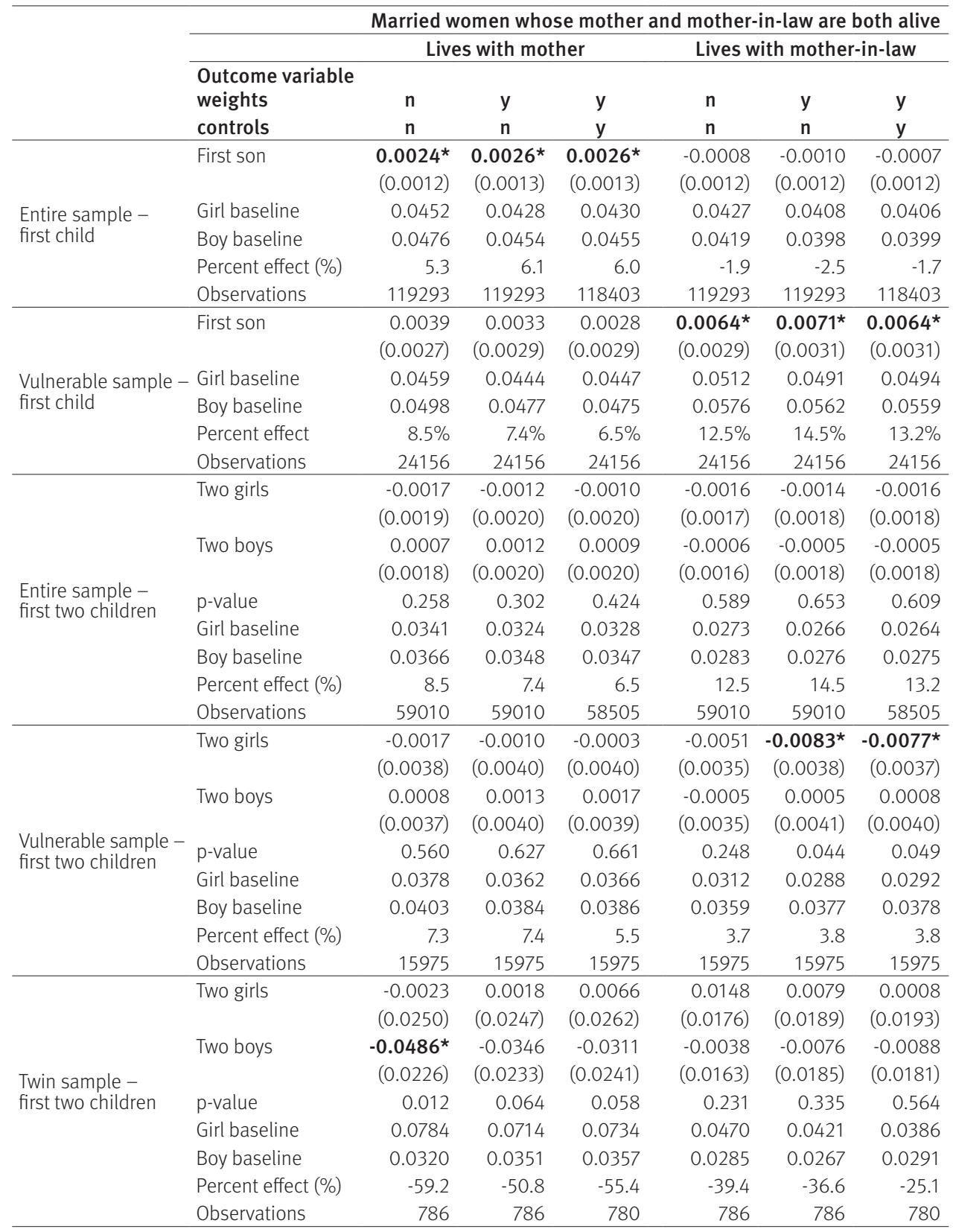

Source: PNAD 2004-2009, 2011.

Note: Robust Standard erros p-values significance: $+0.10 * 0.05 * \star 0.01$.

Controls are woman's age, age cubed, age of first child, years of education, and dummies indicating region, survey year, and rural location.

P-value is the significance of the test of differences in coefficients two girls \& two boys. 
Results on grandmother presence indicate that grandmothers are more likely to be present when there are two girls in the household. The bounding exercises yield some hints regarding girl bias, even for paternal grandmothers, yet conditional OLS results point toward a boy bias in some cases.

\section{Additional siblings}

In Table 4, I find that for the entire analytical sample, women are about 0.65 percentage points more likely to have an additional child if their first child is a son rather than a daughter. This could be the result of the increased likelihood of being in union upon having a firstborn son. However, the magnitude of this difference is larger than the difference in union status correlating with sex of the first child (about 0.28 percentage points) so it does not explain the entire differential; there may indeed be a girl bias among some parents.

In attempt to address the concern of selection bias, I also test (but do not include in the table) the relationship between the sex of the first child and the likelihood of having a third child. This strategy eliminates the need to consider the sex of the first two children - which of course is a function of the sex of the first child - so that selection into having a second child can be avoided. However, this correlation is not statistically significant.

When examining the sex of the first two children, having two children of the same sex results in a statistically significant increase in the likelihood of having an additional child, reflecting a preference for sex variety. Additionally, it is interesting to note that the magnitude is similar for the population as a whole and for the vulnerable population, and thus, not a result driven by poverty. Indeed, in addition to the preference for variety, for the population as a whole, evidence of differential fertility stopping behavior can be observed when examining the first two children and for mothers of twins. Mothers of twins are $20 \%$ more likely to have another child if they have a pair of girls rather than a pair of boys. The magnitude of the difference is smaller for the overall population, but the difference is still significant at $15 \%$. Comparing the differences in likelihood of having a third child between mothers with two boys and two girls is not statistically significant in the vulnerable population, perhaps because this population is more likely to have additional children anyway. 
TABLE 4

OLS Regressions of additional children based on child's sex Brazil - 2004/2011

\begin{tabular}{|c|c|c|c|c|}
\hline & \multirow{3}{*}{$\begin{array}{l}\text { Outcome variable } \\
\text { weights } \\
\text { controls }\end{array}$} & \multicolumn{3}{|c|}{ More children } \\
\hline & & $\mathrm{n}$ & $\mathrm{y}$ & $y$ \\
\hline & & $\mathrm{n}$ & $\mathrm{n}$ & $y$ \\
\hline \multirow{6}{*}{$\begin{array}{l}\text { Entire sample - } \\
\text { first child }\end{array}$} & First son & $0.0048^{\star}$ & $0.0053^{*}$ & 0.0069 ** \\
\hline & & $(0.0022)$ & $(0.0024)$ & $(0.0020)$ \\
\hline & Girl baseline & 0.4727 & 0.4690 & 0.4677 \\
\hline & Boy baseline & 0.4775 & 0.4743 & 0.4743 \\
\hline & Percent effect (\%) & 1.0 & 1.1 & 1.4 \\
\hline & Observations & 214747 & 214747 & 212549 \\
\hline \multirow{6}{*}{$\begin{array}{l}\text { Vulnerable sample - } \\
\text { first child }\end{array}$} & First son & -0.0025 & -0.0037 & 0.0012 \\
\hline & & $(0.0047)$ & $(0.0051)$ & $(0.0043)$ \\
\hline & Girl baseline & 0.6416 & 0.6422 & 0.6395 \\
\hline & Boy baseline & 0.6391 & 0.6386 & 0.6407 \\
\hline & Percent effect (\%) & -0.4 & -0.6 & 0.1 \\
\hline & Observations & 42548 & 42548 & 42424 \\
\hline \multirow{9}{*}{$\begin{array}{l}\text { Entire sample - } \\
\text { first two children }\end{array}$} & Two girls & $0.0381^{\star \star}$ & $0.0376^{\star \star}$ & $0.0352^{\star \star}$ \\
\hline & & $(0.0036)$ & $(0.0039)$ & $(0.0037)$ \\
\hline & Two boys & $0.0249 \star \star$ & $0.0245^{\star \star}$ & $0.0286^{\star *}$ \\
\hline & & $(0.0034)$ & $(0.0038)$ & $(0.0035)$ \\
\hline & p-value & 0.001 & 0.004 & 12.9 \\
\hline & Girl baseline & 0.3113 & 0.3064 & 30.3 \\
\hline & Boy baseline & 0.2981 & 0.2933 & 0.2965 \\
\hline & Percent effect (\%) & -4.2 & -4.3 & -2.1 \\
\hline & Observations & 101296 & 101296 & 100116 \\
\hline \multirow{9}{*}{$\begin{array}{l}\text { Vulnerable sample - } \\
\text { first two children }\end{array}$} & Two girls & $0.0394^{\star *}$ & $0.0340 * \star$ & $0.0344^{\star \star}$ \\
\hline & & (0.0075) & $(0.0082)$ & $(0.0077)$ \\
\hline & Two boys & $0.0311^{\star *}$ & $0.0278^{\star \star}$ & $0.0302^{* *}$ \\
\hline & & $(0.0073)$ & $(0.0080)$ & (0.0075) \\
\hline & p-value & 0.329 & 0.507 & 0.628 \\
\hline & Girl baseline & 0.4528 & 0.4492 & 0.4488 \\
\hline & Boy baseline & 0.4445 & 0.4430 & 0.4446 \\
\hline & Percent effect (\%) & -1.8 & -1.4 & -0.9 \\
\hline & Observations & 27099 & 27099 & 27014 \\
\hline \multirow{9}{*}{$\begin{array}{l}\text { Twin sample - } \\
\text { first two children }\end{array}$} & Two girls & $0.0739 *$ & $0.0863^{* \star}$ & 0.0385 \\
\hline & & $(0.0308)$ & $(0.0334)$ & $(0.0309)$ \\
\hline & Two boys & 0.0108 & 0.0051 & -0.0198 \\
\hline & & $(0.0306)$ & $(0.0327)$ & $(0.0300)$ \\
\hline & p-value & 0.023 & 0.007 & 0.040 \\
\hline & Girl baseline & 0.3209 & 0.3230 & 0.3040 \\
\hline & Boy baseline & 0.2578 & 0.2418 & 0.2457 \\
\hline & Percent effect (\%) & -19.7 & -25.1 & -19.2 \\
\hline & Observations & 1405 & 1405 & 1391 \\
\hline
\end{tabular}

Source: PNAD 2004-2009, 2011.

Note: Robust standard erros p-values significance: $+0.10 * 0.05$ ** 0.01 .

Controls are woman's age, age cubed, age of first child, years of education, a dummy for if her mother is alive, and dummies indicating region, survey year, and rural location.

P-value is the significance of the test of differences in coefficients two girls \& two boys. 


\section{Discussion}

This paper examined if children's sex is associated with household structure in Brazil using nationally representative data from 2004-2011. I do not find a significant impact of the sex of the firstborn child on the mother's union status for the population as whole. Yet when examining the most vulnerable women - those who gave birth at age 18 or younger and who have not yet finished high school - I find a one percent increase in the likelihood of being in union for women whose first child is a son, rather than a daughter. Results are stronger when considering the sex composition of the first two children: in the entire population, as well as in the more vulnerable subpopulation, women with two girls are less likely to be in union than women with two boys. Additionally, I examine the living arrangements of children whose mother is deceased. Again, boys are more likely than girls to be sons of the household head. Although I cannot determine whether these findings are due to sex bias, a more costly investment in raising daughters, or recognition of the comparative advantage that fathers have in parenting sons, by any theory, there is concern that girls may be disadvantaged with respect to not having fathers in the household.

I test if the sex of a woman's children affects the likelihood of her mother being present in the household, a possible mechanism for ameliorating welfare loss from a father's absence. I find a significant result for the most vulnerable population when examining the sex composition of the first two children: among the most vulnerable women who have not completed high school and who gave birth when they were teenagers, there is an increased likelihood of a grandmother presence when the first two children are girls. This is also the case among mothers of twins. The contrast in OLS results between women in union and all women suggest the presence of the partner also plays an important role in determining if the grandmother lives in the home. On this regard, the results from Lee's bounds are also interesting: with both bounds below zero, for the entire population I find an increased likelihood of paternal grandmothers to live with daughters-in-law with firstborn daughters than daughters-in-law with firstborn sons. This result could support granddaughter bias theory, even along the patrilineal line. It must be noted that these estimates apply to those who would not be persuaded by child's sex to divorce; perhaps a greater appreciation for girls has been passed from mother to son, so that sons are less likely to divorce and this comes through in the granddaughter preference by grandmothers. The contrasting OLS results of increased maternal grandmother presence with a first son is particularly interesting in connection with the previous results on grandmother presence for the population as a whole. Only when limited to women in union is a grandmother's presence significantly correlated with the sex of her grandchild. This contrast suggests that the husband may be a key player in deciding household composition of whether or not the couple will be living with the wife's mother. On the other hand, maternal grandmothers in charge of household composition, whether or not their sons-in-law remain present, may be more permissive 
towards the fathers of their grandsons, considering that a male influence is important for the children. At this point, however, as the bounds are the most conservative estimate, these results are more suggestive than definitive, but they do encourage additional research on the hypothesis that child's sex influences grandmother presence, as well as into how intra-household bargaining may influence living arrangements.

Previous evidence of grandmother bias for granddaughters has been found in South Africa (DUFLO, 2003), but not in Brazil (PONCZEK, 2011) in studies that examine the influence of pensions on co-residing grandchildren. However, there are still reasons to consider grandmother bias for granddaughters to be plausible. Granddaughters rather than grandsons - may be more likely to care for grandmothers in old age. Lee, Dwyer, and Coward (1993) show that in the US, adult children are more likely to provide care to a parent of the same sex, and ailing elders are more likely to receive care from a child of the same sex. Because the substantial majority of elderly parents requiring care from children are mothers, this tendency toward sex consistency in the caregiving relationship partially accounts for the fact that daughters are more likely than sons to be involved in parental care. Descriptive data of women who have an equal number of male and female children, none of whom is deceased, supports this care preference in Brazil (Figure 4). At different ages, the graph compares the fraction of women who live with a son to the fraction of women who live with a daughter (excluding women who live with children of both sexes). At age 50, more women live with their sons, whereas this trend changes at around 70 years old. By the age of 90 , a woman is almost twice more likely to live with a daughter than with a son. While the PNAD survey is not detailed enough with regard to household relationship data to repeat the graph for granddaughters, it would not be an unlikely extrapolation to think that granddaughters - in contrast to grandsons - may be more supportive of grandmothers, which could explain grandmother bias. On the other hand, higher rates of grandmothers living with granddaughters in contrast to grandsons could be a result of fathers being more likely to live with their sons: mothers living without partners may live with their own mothers for economic or childcare support. Whatever the reason, though the grandmothers in the sample are relatively young and able to promote child development, they may become burdens for their granddaughters at a later stage in life.

Regarding additional children born into the family, I find strong evidence of a preference for variety in children's sex: mothers of two boys or two girls are more likely to have an additional child than mothers of a boy and a girl. This preference for variety has also been found in Europe (HANK; KOHLER, 2000) and the United States (DAHL; MORETTI, 2008). I have not found studies documenting preference for variety in developing nations, as most focus on son preference, even though a greater preference for variety could exist. However, in Brazil, I also find mothers of two girls are more likely to have additional children than mothers of two boys. In an attempt to address the concern of selection bias, I also test (but do not include in the table) the relationship 
between the sex of the first child and the likelihood of having a third child. This strategy eliminates the need to consider the sex of the first two children - which of course is a function of the sex of the first child - so that selection into having a second child can be avoided. However, this correlation is not statistically significant. This result in itself is an important finding in comparison to results from the United States. Dahl and Moretti (2008) find a significant increase in the likelihood of having a third child if the first child is a girl. Thus, in comparison, Brazil may be less "biased" regarding children's sex preference and additional children. Comparing the differences in the likelihood of having a third child between mothers with two boys and two girls is not statistically significant in the vulnerable population. This finding echoes that of Filmer, Friedman, and Schady (2008), who indicate that at smaller parities, usually occurring because women are more educated and have fewer children, son preferences in South Asia are more strongly manifest. In Brazil, this vulnerable population has not finished high school and may have more children, which could explain why the son preference does not come through as statistically significant, even though the magnitudes of the coefficients are aligned with a son preference.

FIGURE 4

Fraction of women (1) who live with son or daughter

Brazil - 2004/2011

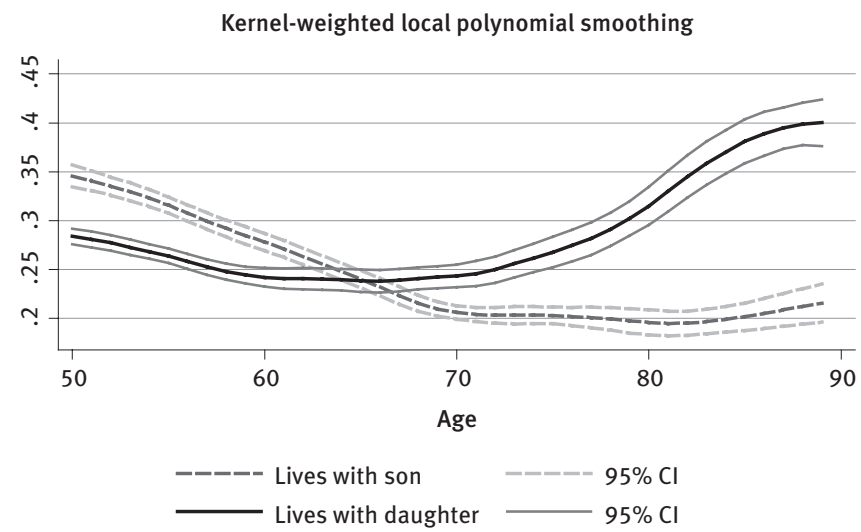

Source: PNAD 2004-2009, 2011.

(1) Women with equal number of sons and daughters who have no deceased children.

Note: Excludes women living with children of both genders.

Although I cannot determine whether these findings are due to sex bias, a more costly investment in raising daughters, or recognition of the comparative advantage that fathers have in parenting sons, by any theory, there is concern that girls may be disadvantaged due to not having fathers in the household. While these findings support the boy preference hypotheses, other hypotheses could also support these findings. For example, fathers may have a comparative advantage in caring for sons as grandmothers 
have a comparative advantage in caring for granddaughters. Though we may not know the reason behind the association, it is important because of the welfare impacts. Absent fathers - generally higher income earners - will be contributing to a structural bias disadvantaging girls. Children in larger families - those with daughters born first will have fewer resources as they are divided among a larger number of children.

This study has several limitations. Data do not indicate if the co-residing partner of the mother is the child's father. This limitation also affects the analysis for paternal grandparents, which can only be done if the mother's partner is in the household. However, it cannot be ascertained whether these grandparents are the true paternal grandparents without knowing whether the male partner is the father. Additionally, the model used for estimating is a comparison of means model of dichotomous outcome variables, which implies poor goodness-of-fit measures, even with control variables. Additionally, the analysis uses several years of data pooled. While this approach does provide conclusions regarding overarching trends, the need to pool the data in order to achieve a degree of statistical significance highlights how subtle these tendencies are.

Nevertheless, this research is a first glimpse into the influence of child's sex on household composition considering not just father preference and fertility stopping behavior as typically studied, but also grandmother presence. Further research is needed to determine if these differences translate into welfare implications. A cursory analysis in the appendix examines household income, mother's hours spent on work and chores, and subsequent children's education outcomes. Although no difference was found in household income, the schooling attendance of the following child is higher when the older sibling is male; mothers spend fewer hours doing work and chores when they have males. However, in spite of there being continued evidence that families with earlier born males are more advantaged than females, this analysis does not determine that the difference in household structure from child's sex bias is the cause. More research is needed on this matter, particularly examining how grandparents may be supporting child development as well as considering how mother characteristics influence child welfare outcomes in different household structures.

Although Brazil does not have overt evidence of preference for children's sex, such as sex-selective abortion, a small but statistically significant differential in household composition related to child's sex has been found to support the son bias hypothesis. If fertility continues to decline, son preference may become more apparent. Differential fertility stopping behavior was found among the entire population, but not among the vulnerable population, which has an overall higher fertility rate. It is important that policy makers pay close attention to determine if trends are changing and consider measures that may influence cultural attitudes. While direct policy interventions would be blunt, raising awareness of underlying preferences may help people acknowledge biases in order to overcome them. 


\section{References}

AMATO, P. R. The consequences of divorce for adults and children. Journal of Marriage and Family, v. 62, n. 4, p. 1269-87, 2000. Available in: 〈https://doi.org/10.1111/j.1741-3737.2000.01269.x〉.

AMATO, P. R.; GILBRETH, J. G. Nonresident fathers and children's well-being: a meta-analysis. Journal of Marriage and Family, v. 61, n. 3, p. 557-73, 1999. Available in: 〈https://doi. org $/ 10.2307 / 353560$ >.

ANGRIST, J. D.; EVANS, W. N. Children and their parents' labor supply: evidence from exogenous variation in family size. The American Economic Review, v. 88, n. 93, p. 450-77, 1998.

AQUILINO, W. S. The life course of children born to unmarried mothers: childhood living arrangements and young adult outcomes. Journal of Marriage and the Family, v. 58, n. 2, p. 293-310, 1996.

AYLLÓN, S.; FERREIRA-BATISTA, N. N. "Mommy, i miss daddy". The effect of family structure on children's health in Brazil. Economics \& Human Biology, v. 19 (C), p. 75-89, 2015. Available in: 〈https://doi.org/10.1016/j.ehb.2015.08.001〉.

BRAVER, S. L.; GRIFFIN, W. A.; COOKSTON, J. T. Prevention programs for divorced nonresident fathers. Family Court Review, v. 43, n. 1, p. 81-96, 2005. Available in: 〈https://doi. org/10.1111/j.1744-1617.2005.00009.x>.

CATALANO, R.; BRUCKNER, T.; ANDERSON, E.; GOULD, J. B. Fetal death sex ratios: a test of the economic stress hypothesis. International Journal of Epidemiology, v. 34, n. 4, p. 944-48, 2005. Available in: 〈https://doi.org/10.1093/ije/dyi081〉.

CHIAVEGATTO FILHO, A. D. P.; KAWACHI, I. Are sex-selective abortions a characteristic of every poor region? Evidence from Brazil. International Journal of Public Health, v. 58, n. 3, p. 395-400, 2013. Available in: 〈https://doi.org/10.1007/s00038-012-0421-6〉.

DAHL, G. B.; MORETTI, E. The demand for sons. The Review of Economic Studies, v. 75, n. 4, p. 1085-1120, 2008.

DELEIRE, T.; KALIL, A. Good things come in threes: single-parent multigenerational family structure and adolescent adjustment. Demography, v. 39, n. 2, p. 393-413, 2002. Available in: 〈https:// doi.org/10.1353/dem.2002.0016>.

DUFLO, E. Grandmothers and granddaughters: old-age pensions and intrahousehold allocation in South Africa. World Bank Economic Review, v. 17, n. 1, p. 1-25, 2003. Available in: 〈https:// doi.org/10.1093/wber/lhg013>.

DUNIFON, R.; KOWALESKI-JONES, L. The influence of grandparents in single-mother families. Journal of Marriage and Family, v. 69, n. 2, p. 465-81, 2007.

EMERSON, P. M.; SOUZA, A. P. Child labor, school attendance, and intrahousehold gender bias in Brazil. The World Bank Economic Review, v. 21, n. 2, p. 301-316, 2007.

FILMER, D.; FRIEDMAN, J.; SCHADY, N. Development, modernization, and son preference in fertility decisions. The World Bank, September 2008. (Policy Research Working Paper, 4716). Available in: 〈https://openknowledge.worldbank.org/handle/10986/6995〉.

HAMOUDI, A.; NOBLES, J. Do daughters really cause divorce? Stress, pregnancy, and family composition. Demography, v. 51, n. 4, p. 1423-49, 2014. Available in: 〈https://doi.org/10.1007/ s13524-014-0305-x>.

HANK, K.; KOHLER, H-P. Gender preferences for children in Europe: empirical results from 17 FFS countries. Demographic Research, v. 2, n. 1, p. 133-144, 2000. 
JENSEN, R. T. Equal treatment, unequal outcomes? Generating sex inequality through fertility behavior. Harvard University, 2003 (Working Paper). Available in: 〈http://idfresearch.org/pdf/ wp0303.pdf〉.

JHA, P. et al. Trends in selective abortions of girls in India: analysis of nationally representative birth histories from 1990 to 2005 and census data from 1991 to 2011. The Lancet, v. 377, n. 9781, p. 1921-1928, 2011.

LEE, D. S. Training, wages, and sample selection: estimating sharp bounds on treatment effects. The Review of Economic Studies, v. 76, n. 3, p. 1071-1102, 2009.

LEE, G. R.; DWYER, J. W.; COWARD, R. T. Gender differences in parent care: demographic factors and same-gender preferences. Journal of Gerontology, v. 48, n. 1, p. S9-16, 1993. Available in: 〈https://doi.org/10.1093/geronj/48.1.S9〉.

LUNDBERG, S. Sons, daughters, and parental behavior. Oxford Review of Economic Policy, v. 21, n. 3, p. 340-56, 2005. Available in: 〈https://doi.org/10.1093/oxrep/gri020〉.

MAIA, A. G.; SAKAMOTO, C. S. The impacts of rapid demographic transition on family structure and income inequality in Brazil, 1981-2011. Population Studies, v. 70, n. 3, p. 293-309, 2016. Available in: 〈https://doi.org/10.1080/00324728.2016.1201588〉.

MARTELETO, L. J.; NOONAN, M. C. Grandmothers as childcare providers in Brazil. In: THE ANNUAL MEETINGS OF THE POPULATION ASSOCIATION OF AMERICA. Proceedings... Chicago: PAA, 1998. Available in: 〈http://myweb.uiowa.edu/noona/grandpaper.pdf〉.

MCLANAHAN, S.; TACH, L.; SCHNEIDER, D. The causal effects of father absence. Annual Review of Sociology, v. 39, p. 399-427, 2013. Available in: 〈https://doi.org/10.1146/annurevSOC-071312-145704>.

MELO, N. C. V. de et al. Household arrangements of elderly persons in Brazil: analyses based on the National Household Survey Sample (2009). Revista Brasileira de Geriatria e Gerontologia, v. 19, n. 1, p. 139-51, 2016. Available in: 〈https://doi.org/10.1590/1809-9823.2016.15011〉.

MUTCHLER, J. E.; BAKER, L. A. The implications of grandparent coresidence for economic hardship among children in mother-only families. Journal of Family Issues, v. 30, n. 11, p. 1576-97, 2009. Available in: 〈https://doi.org/10.1177/0192513X09340527〉.

NORBERG, K. Partnership status and the human sex ratio at birth. Proceedings of the Royal Society of London. Series B: Biological Sciences, v. 271, n. 1555, p. 2403-2410.

PONCZEK, V. Income and bargaining effects on education and health in Brazil. Journal of Development Economics, v. 94, n. 2, p. 242-53, 2011. Available in: 〈https://doi.org/10.1016/ j.jdeveco.2010.01.011>.

PRICE, J. Parent-child quality time does birth order matter? Journal of Human Resources, v. 43, n. 1, p. 240-65, 2008.

RENDALL, M. Structural change in developing countries: has it decreased gender inequality? World Development, v. 45, p. 1-16, May 2013. Available in: 〈https://doi.org/10.1016/ j.worlddev.2012.10.005〉.

SARKADI, A.; KRISTIANSSON, R.; OBERKLAID, F.; BREMBERG, S. Fathers' involvement and children's developmental outcomes: a systematic review of longitudinal studies. Acta Pædiatrica, v. 97, n. 2, p. 153-58, 2008. Available in: 〈https://doi.org/10.1111/j.1651-2227.2007.00572.x〉.

SCHADY, N. Early childhood development in Latin America and the Caribbean. The World Bank, 2006 (Policy Research Working Paper Series, 3869). Available in: 〈http://ideas.repec.org/p/ wbk/wbrwps/3869.html. 
SELTZER, J. A. Relationships between Fathers and children who live apart: the father's role after separation. Journal of Marriage and Family, v. 53, n. 1, p. 79-101, 1991. Available in: 〈https:// doi.org/10.2307/353135>.

TAUCHMANN, H. Lee's treatment effect bounds for non-random sample selection-an implementation in Stata. Technische Universität Dortmund, 2013 (Discussion paper, 35/13). Available in: 〈https://eldorado.tu-dortmund.de/handle/2003/30828〉.

THOMAS, D.Like father, like son; like mother, like daughter: parental resources and child height. The Journal of Human Resources, v. 29, n. 4, p. 950-88, 1994.

THOMSON, E.; HANSON, T. L.; MCLANAHAN, S. S. Family structure and child well-being: economic resources vs. parental behaviors. Social Forces, v. 73, n. 1, p. 221-42, 1994. Available in: <https:// doi.org/10.1093/sf/73.1.221>.

TRIVERS, R. L.; WILLARD, D. E. Natural selection of parental ability to vary the sex ratio of offspring. Science, v. 179, n. 4068, p. 90-92, 1973.

WHEELOCK, J.; OUGHTON, E.; BAINES, S. Getting by with a little help from your family: toward a policy-relevant model of the household. Feminist Economics, v. 9, n. 1, p. 19-45, 2003.

WILSON, M. N. Child development in the context of the black extended family. American Psychologist, v. 44, n. 2, p. 380-85, 1989. Available in: 〈http://dx.doi.org/10.1037/0003066X.44.2.380>.

ZHU, W. X.; LU, L.; HESKETH, T. China's excess males, sex selective abortion, and one child policy: analysis of data from 2005 National Intercensus Survey. British Medical Journal, n. 338, 2009. Available in: 〈https://doi.org/10.1136/bmj.b1211〉.

\section{About the author}

Sarah Anne Reynolds is development economist whose work has focused on family dynamics, often in non-nuclear families and their relation to child welfare.

\section{Contact address}

2121 Berkeley Way \#5302

Berkeley, CA 94720, United States of America

\section{Resumo}

Sexo da criança e estrutura domiciliar no Brasil: viés dos pais e dos avós?

O Brasil tem um alto índice de mulheres vivendo sozinhas com seus filhos e de domicílios intergeracionais, nos quais há presença de pais e avós. A estrutura domiciliar pode influenciar o desenvolvimento infantil. Apesar de o Brasil não apresentar evidências de aborto seletivo por sexo, a preferência por gênero ainda pode estar sutilmente presente. Testamos se a corresidência com o pai, a corresidência com a avó e o nascimento de um próximo filho estão associados com o sexo das crianças no Brasil. Usando uma amostra representativa nacionalmente, foram realizadas regressões OLS, considerando o sexo do primeiro e do segundo filho como variáveis exógenas. Mulheres com filhas em menor ordem de nascimento são mais propensas a serem 
solteiras. Encontraram-se evidências de que as avós maternas são mais propensas a viver com netas do que com netos, o que pode amenizar as perdas econômicas da falta da presença do pai no domicílio. As mulheres com filhas em menor ordem de nascimento são mais propensas a terem filhos adicionais, sugerindo a preferência por filho homem. A literatura anterior tem um enfoque na presença do pai. Aqui inclui-se a avó para aumentar a perspectiva feminina. Estes dados contribuem para a literatura em relação à preferência pelo sexo das crianças, que se concentra na análise da figura masculina (pais); analisamos dados sobre as avós para incluir mulheres.

Palavras-chave: Viés de gênero. Composição do domicílio. Avós. Brasil.

\section{Resumen}

El sexo del niño y la estructura del hogar en Brasil: ¿preferencias de padres y abuelas?

Brasil tiene una alta tasa de madres viviendo solas con sus hijos y una alta tasa de corresidencia intergeneracional, con presencia de padres y abuelos. Estos dos tipos de organizaciones familiares podrían influir en el bienestar de los niños. Aunque no hay evidencia en Brasil de preferencias de en aborto selectivo con base en el género, es posible que estas preferencias se presenten de manera más sutil. En este estudio se analiza si la estructura del hogar (corresidencia con el padre, corresidencia con la abuela y el nacimiento de los siguientes hijos) en Brasil está asociada con el sexo del niño. Usando una encuesta nacionalmente representativa y considerando el sexo del primer y segundo hijo como variables exógenas se hicieron regresiones OLS. Los resultados muestran que las mujeres con hijas en menor orden de nacimiento son más propensas a ser solteras. Además se encuentra evidencia sugerente de que las abuelas maternas son más propensas a vivir con nietas que con nietos, lo que puede compensar la pérdida económica por la falta del padre de los hijos en el domicilio. Las mujeres con hijas en menor orden de nacimientos son más propensas a tener hijos adicionales, lo que sugiere la preferencia por el hijo varón. Si bien la literatura previa a este estudio se enfoca sobre la presencia del padre en el hogar, el presente trabajo incluye a la abuela para aumentar la perspectiva femenina. Estos datos contribuyen a la literatura en relación con la preferencia por el sexo de los hijos que se concentra en el análisi de la figura masculina (padres).

Palabras clave: Sesgo de género. Composicion del hogar. Abuelas. Brasil.

Received for publication in $02 / 07 / 2018$ Approved for publication in 26/12/2018

\section{APPENDIX}

\section{Welfare outcomes}

As discussed in the introduction, a father bias for sons is most disconcerting if the mother bias for daughters is not enough to compensate for the financial advantages men usually have. Examining welfare outcomes can provide evidence of a sons' unfair advantage. Dahl and Moretti (2008) find evidence of a significant advantage for families with firstborn sons in the United States (larger household wealth, better educational outcomes), and 
Jensen (2003) finds girls in India to be disadvantaged in educational outcomes due to larger family sizes resulting from differential fertility stopping behavior. In Brazil, I find some evidence of disadvantage for families with girls over families with boys, but not as consistently as found elsewhere.

I repeat the same specifications described in the methods section using following outcome variables: per capita household income, the next child's enrollment status (preschool for children ages 3 \& 4, school for children 6 and older), and the mother's combined total hours spent working on the job and in the household.

In the first columns of Table A1, with the exception of the first two children in the vulnerable sample, families with boys have a higher per capita household income. Yet this finding is statistically significant only for the first two children in the entire population and for twins, and loses significance when controls are added. While this economic disadvantage does not manifest strongly, it does raise concerns.

To examine the impact of sex on education, I analyze the impact of the gender of the firstborn child on the second child's education outcome, as well as the impact of the gender composition of the first two children on the third child's educational outcome. I find that the gender of the first child influences whether the second child attends preschool and the gender of the first two children influences whether the third child attends school. In both cases, siblings of boys are more likely to attend school. This suggests that children in families with more girls will be disadvantaged in school.

The mother's total workload is also an important welfare variable, though perhaps more for themselves than for their children. Women's working hours are about a quarter of an hour a week shorter when their first-born is male. This differential rises slightly, to about half an hour per week, when examining the sample of vulnerable women. When looking at the two boys and two girls scenario, for the population as a whole, the working hours of women with two boys compared to those of women with two girls is about a half an hour less a week. This difference is about twice the work differential among the firstborn, suggesting an additive impact. However, when examining the first two children in the vulnerable sample, the difference in the workload of mothers of two boys and two girls is not statistically significant. There is also no statistically significant impact of gender composition on the work behavior of the mothers of twins. Perhaps among these women who already have much work (the impoverished \& mothers of twins) the sex of the children is not relevant enough to change the working hours. There are two main hypotheses which could explain why women work more when having girls rather than boys. One of them is they could be investing more in their daughters and the other one is they could be compensating for absent fathers or for fathers investing less in daughters. More research is needed to fully grasp the mechanism. Interestingly, returning to the subsample of children without mothers, despite having found that girls are less likely to live with fathers, there are no significant differences in household income-per-capita nor in educational outcomes by sex. Overall, explorations of welfare impacts indicate that some disadvantages in families with girls may be exacerbating the existing gender gap in Brazil. 
TABLE A1

OLS Regressions of welfare outcomes based on child sex

\begin{tabular}{|c|c|c|c|c|c|c|c|}
\hline & \multirow{3}{*}{$\begin{array}{c}\text { Outcome variable } \\
\text { weights } \\
\text { controls }\end{array}$} & \multicolumn{3}{|c|}{ Per capita $\mathrm{HH}$ income } & \multicolumn{3}{|c|}{ Next child attends preschool } \\
\hline & & $\mathrm{n}$ & $y$ & $y$ & $\mathrm{n}$ & $y$ & y \\
\hline & & $\mathrm{n}$ & $\mathrm{n}$ & $\mathrm{y}$ & $\mathrm{n}$ & $\mathrm{n}$ & $\mathrm{y}$ \\
\hline \multirow{6}{*}{$\begin{array}{l}\text { Entire sample - } \\
\text { first child }\end{array}$} & First son & 4.2880 & 3.1788 & 0.2732 & 0.0119 & $0.0155+$ & $0.0130+$ \\
\hline & & -2.9410 & -3.3755 & -3.0161 & -0.0072 & -0.0080 & -0.0076 \\
\hline & Girl baseline & 420.1353 & 433.5012 & 436.4606 & 0.4768 & 0.4848 & 0.4863 \\
\hline & Boy baseline & 424.4233 & 436.6800 & 436.7337 & 0.4887 & 0.5003 & 0.4993 \\
\hline & Percent effect (\%) & 1.0 & 0.7 & 0.1 & 2.5 & 3.2 & 2.7 \\
\hline & Observations & 210100 & 210100 & 207941 & 19161 & 19161 & 18933 \\
\hline \multirow{6}{*}{$\begin{array}{l}\text { Vulnerable sample } \\
\text { - first child }\end{array}$} & First son & 2.3491 & 2.0614 & 1.3293 & $0.0280^{\star}$ & $0.0253+$ & $0.0301^{*}$ \\
\hline & & -1.8795 & -2.1774 & -1.9984 & -0.0135 & -0.0151 & -0.0146 \\
\hline & Girl baseline & 187.9399 & 194.1274 & 194.5374 & 0.3678 & 0.3822 & 0.3795 \\
\hline & Boy baseline & 190.2891 & 196.1889 & 195.8667 & 0.3958 & 0.4075 & 0.4096 \\
\hline & Percent effect (\%) & 1.2 & 1.1 & 0.7 & 7.6 & 6.6 & 7.9 \\
\hline & Observations & 41928 & 41928 & 41807 & 5148 & 5148 & 5134 \\
\hline \multirow{9}{*}{$\begin{array}{l}\text { Entire sample - } \\
\text { first two children }\end{array}$} & Two girls & $-10.2359^{\star}$ & $-10.0462^{\star}$ & -6.3380 & 0.0105 & 0.0156 & 0.0079 \\
\hline & & -4.1000 & -4.6115 & -4.0404 & -0.0146 & -0.0165 & -0.0160 \\
\hline & Two boys & 5.4918 & 6.3232 & 0.3051 & $0.0266+$ & 0.0226 & 0.0129 \\
\hline & & -4.2285 & -4.7136 & -4.1498 & -0.0145 & -0.0163 & -0.0157 \\
\hline & $p$-value & 0.1 & 0.2 & 15.3 & 32.7 & 70.6 & 78.0 \\
\hline & Girl baseline & 31300.1 & 32289.7 & 32850.2 & 38.4 & 40.7 & 40.4 \\
\hline & Boy baseline & 328.7287 & 339.2662 & 335.1448 & 0.3998 & 0.4135 & 0.4093 \\
\hline & Percent effect (\%) & 5.0 & 5.1 & 2.0 & 4.2 & 1.7 & 1.2 \\
\hline & Observations & 99412 & 99412 & 98252 & 6604 & 6604 & 6514 \\
\hline \multirow{9}{*}{$\begin{array}{l}\text { Vulnerable sample } \\
\text { - first two children }\end{array}$} & Two girls & 2.9363 & 1.6151 & 3.0897 & 0.0201 & 0.0242 & 0.0243 \\
\hline & & -2.6869 & -3.1900 & -2.9657 & -0.0227 & -0.0257 & -0.0249 \\
\hline & Two boys & 0.0739 & -1.3116 & -1.4614 & 0.0111 & 0.0025 & 0.0013 \\
\hline & & -236.9 & -278.4 & -257.7 & -2.2 & -2.5 & -2.5 \\
\hline & p-value & 34.1 & 41.4 & 17.1 & 72.6 & 45.5 & 41.4 \\
\hline & Girl baseline & 163.9668 & 167.9298 & 169.0853 & 0.3524 & 0.3753 & 0.3765 \\
\hline & Boy baseline & 161.1044 & 165.0031 & 164.5342 & 0.3433 & 0.3536 & 0.3535 \\
\hline & Percent effect (\%) & -1.7 & -1.7 & -2.7 & -2.6 & -5.8 & -6.1 \\
\hline & Observations & 26742 & 26742 & 26659 & 2648 & 2648 & 2638 \\
\hline \multirow{9}{*}{$\begin{array}{l}\text { Twin sample - } \\
\text { first two children }\end{array}$} & Two girls & $-117.0055+$ & $-114.8341+$ & -16.9779 & -0.2297 & -0.1812 & -0.2396 \\
\hline & & -62.6757 & -66.7496 & -56.6750 & -0.1474 & -0.1593 & -0.1752 \\
\hline & Two boys & -61.6203 & -30.6237 & 4.9514 & -0.0484 & -0.0130 & -0.1002 \\
\hline & & -64.3266 & -69.0485 & -57.3404 & -0.1565 & -0.1675 & -0.1806 \\
\hline & p-value & 28.5 & 10.0 & 61.6 & 12.7 & 20.6 & 30.9 \\
\hline & Girl baseline & 457.8814 & 455.0927 & 501.6848 & 0.2703 & 0.3054 & 0.3029 \\
\hline & Boy baseline & 513.2665 & 539.3031 & 523.6141 & 0.4516 & 0.4736 & 0.4424 \\
\hline & Percent effect & 12.1 & 18.5 & 4.4 & 67.1 & 55.1 & 46.1 \\
\hline & Observations & 1374 & 1374 & 1360 & 84 & 84 & 84 \\
\hline
\end{tabular}




\begin{tabular}{|c|c|c|c|c|c|c|c|}
\hline & \multirow{3}{*}{$\begin{array}{l}\text { Outcome } \\
\text { variable } \\
\text { weights } \\
\text { controls }\end{array}$} & \multicolumn{3}{|c|}{ Next child attends school } & \multicolumn{3}{|c|}{ Mothers hours of work/chores } \\
\hline & & $\mathrm{n}$ & y & y & $\mathrm{n}$ & y & y \\
\hline & & $\mathrm{n}$ & $\mathrm{n}$ & y & $\mathrm{n}$ & $\mathrm{n}$ & y \\
\hline \multirow{6}{*}{$\begin{array}{l}\text { Entire sample - } \\
\text { first child }\end{array}$} & First son & 0.0015 & 0.0003 & -0.0003 & $-0.3025^{\star}$ & -0.2576 & $-0.2934+$ \\
\hline & & -0.0015 & -0.0015 & -0.0015 & -0.1488 & -0.1658 & -0.1607 \\
\hline & Girl baseline & 0.9742 & 0.9777 & 0.9781 & 61.7460 & 62.5703 & 62.6023 \\
\hline & Boy baseline & 0.9756 & 0.9780 & 0.9778 & 61.4435 & 62.3127 & 62.3090 \\
\hline & Percent effect (\%) & 0.1 & 0.0 & 0.0 & -0.5 & -0.4 & -0.5 \\
\hline & Observations & 44568 & 44568 & 43938 & 197178 & 197178 & 195145 \\
\hline \multirow{6}{*}{$\begin{array}{l}\text { Vulnerable sample - } \\
\text { first child }\end{array}$} & First son & 0.0049 & 0.0029 & 0.0022 & $-0.5495+$ & $-0.6520+$ & $-0.5708+$ \\
\hline & & -0.0034 & -0.0034 & -0.0034 & -0.3156 & -0.3502 & -0.3401 \\
\hline & Girl baseline & 0.9614 & 0.9668 & 0.9674 & 53.7751 & 54.5956 & 54.5557 \\
\hline & Boy baseline & 0.9664 & 0.9697 & 0.9696 & 53.2256 & 53.9437 & 53.9848 \\
\hline & Percent effect (\%) & 0.5 & 0.3 & 0.2 & -1.0 & -1.2 & -1.0 \\
\hline & Observations & 12091 & 12091 & 12047 & 39788 & 39788 & 39671 \\
\hline \multirow{9}{*}{$\begin{array}{l}\text { Entire sample - } \\
\text { first two children }\end{array}$} & Two girls & 0.0018 & 0.0025 & 0.0005 & 0.0685 & 0.0872 & 0.1445 \\
\hline & & -0.0060 & -0.0061 & -0.0061 & -0.2586 & -0.2873 & -0.2806 \\
\hline & Two boys & $0.0103+$ & $0.0137^{\star}$ & $0.0124^{*}$ & $-0.5202^{\star}$ & $-0.6278^{\star}$ & -0.7260 ** \\
\hline & & -0.0055 & -0.0054 & -0.0054 & -0.2482 & -0.2764 & -0.2700 \\
\hline & p-value & 18.9 & 7.3 & 5.8 & 4.4 & 2.8 & 0.6 \\
\hline & Girl baseline & 94.5 & 95.1 & 94.9 & 6118.7 & 6190.5 & 6196.1 \\
\hline & Boy baseline & 0.9530 & 0.9617 & 0.9612 & 60.5987 & 61.1904 & 61.0905 \\
\hline & Percent effect (\%) & 0.9 & 1.2 & 1.2 & -1.0 & -1.2 & -1.4 \\
\hline & Observations & 9066 & 9066 & 8896 & 93007 & 93007 & 91908 \\
\hline \multirow{9}{*}{$\begin{array}{l}\text { Vulnerable sample - } \\
\text { first two children }\end{array}$} & Two girls & -0.0001 & 0.0023 & 0.0007 & 0.1079 & 0.2648 & 0.2760 \\
\hline & & -0.0106 & -0.0110 & -0.0108 & -0.4764 & -0.5263 & -0.5143 \\
\hline & Two boys & $0.0194^{\star}$ & $0.0268^{\star \star}$ & $0.0258^{\star \star}$ & -0.0380 & 0.2557 & 0.2240 \\
\hline & & -0.9 & -0.9 & -0.9 & -46.1 & -51.2 & -50.2 \\
\hline & p-value & 8.2 & 2.3 & 1.8 & 78.6 & 98.8 & 92.9 \\
\hline & Girl baseline & 0.9294 & 0.9360 & 0.9357 & 55.1957 & 55.9408 & 55.9522 \\
\hline & Boy baseline & 0.9489 & 0.9605 & 0.9608 & 55.0498 & 55.9317 & 55.9003 \\
\hline & Percent effect (\%) & 2.1 & 2.6 & 2.7 & -0.3 & 0.0 & -0.1 \\
\hline & Observations & 3552 & 3552 & 3536 & 25293 & 25293 & 25214 \\
\hline \multirow{9}{*}{$\begin{array}{l}\text { Twin sample - } \\
\text { first two children }\end{array}$} & Two girls & -0.0235 & 0.0129 & -0.0016 & -0.4317 & 1.8414 & 2.8088 \\
\hline & & -0.0374 & -0.0465 & -0.0373 & -2.3411 & -2.6255 & -2.5676 \\
\hline & Two boys & 0.0093 & 0.0348 & 0.0026 & -0.4716 & 1.0222 & 1.5057 \\
\hline & & -0.0333 & -0.0445 & -0.0350 & -2.3630 & -2.6466 & -2.5665 \\
\hline & p-value & 29.6 & 25.7 & 78.3 & 98.5 & 72.2 & 55.7 \\
\hline & Girl baseline & 0.9487 & 0.9687 & 0.9705 & 63.4081 & 65.0894 & 65.3996 \\
\hline & Boy baseline & 0.9815 & 0.9905 & 0.9747 & 63.3683 & 64.2701 & 64.0964 \\
\hline & Percent effect & 3.5 & 2.3 & 0.4 & -0.1 & -1.3 & -2.0 \\
\hline & Observations & 168 & 168 & 165 & 1290 & 1290 & 1279 \\
\hline
\end{tabular}

Source: PNAD 2004-2009, 2011.

Note: Robust Standard erros pvalues significance: $+0.10 * 0.05 * * 0.01$

Controls are woman's age, age cubed, age of first child, years of education, and dummies indicating region, survey year, and rural location. P-value is the significance of the test of differences in coefficients two girls \& two boys. Source: PNAD 2004-2009, 2011. Note: Robust Standard erros pvalues significance: $+0.10 * 0.05 * * 0.01$.

Controls are woman's age, age cubed, age of first child, years of education, and dummies indicating region, survey year, and rural location. P-value is the significance of the test of differences in coefficients two girls \& two boys. 